\title{
RAPE AND RAPE LAWS: SEXISM IN SOCIETY AND LAW
}

In hundreds of ways, large and small, a woman's life is shaped by the persistent threat of rape: women hesitate to venture out at night without niale escorts, to live alone, to hitchhike, to stay late at the office to work alone, to take certain jobs. Men in prison who live with the threat of homosexual rape are probably the only men in our society who experience fear comparable to that felt by all women. The fear of rape not only inhibits the freedom of women, it also exaggerates the dependency of women upon men. The law concerning forcible rape and the way it functions both influences and is influenced by the relationship between men and women in our society. Yet the legal commentators who have written on the subject have not analyzed rape laws with any sensitivity to this phenomenon. And they have ignored the possibility that rape laws as they are presently conceived, rather than protecting women, might actually work to their disadvantage by hindering prosecution of rapists and by exacerbating the inequality between men and women.

This Comment argues that rape laws are largely based on traditional attitudes about social roles and sexual mores. The structure of the laws, enforcement, and prosecution are all based on untested assumptions about the mcidence of the crime, the notivation of the criminal, and the psychology of the victim. As a result, the laws do not effectively deter rape: police enforcement of complaints is inadequate, and judicial treatment of defendants is oversolicitious. Thus rape laws are not designed, nor do they function, to protect a woman's interest in physical integrity. Indeed, rather than protecting women, the rape laws might actually be a disability for them, simce they reinforce traditional attitudes about social and sexual roles. Although societal attitudes no doubt are responsible for the present construction of rape laws, it is also true that this construction serves to reinforce those attitudes. If the laws were changed to relate more rationally to the reality of the crime and to the goal of sexual equality, attitudes about the crime might also change.

This Comment is concerned only with forcible rape, which generally refers to sexual intercourse accomplished without the consent of the female. ${ }^{1}$ Simce consent is the crucial element in rape, forcible

1. Although few of the total number of rapes are reported to police [see text accompanying notes 8-13 infra], this Comment proceeds on the assumption that the available information describing reported rapes accurately describes all forcible rapes. 
rape may include many kinds of conduct that do not imvolve physical force. California, for instance, defines forcible rape as including situations in which: (1) the victim is legally incapable of giving consent due to her mental condition; (2) her resistance is overcome by force; (3) she is prevented froin resisting by threats or drugs; (4) she is unconscious; or (5) she is deceived into believing the perpetrator is her husband. ${ }^{2}$ Thus it is possible to commit rape without putting the victim in fear. The available data show, however, that nearly all reported rapes involve either verbal threats, the use of a weapon, or physical force. Therefore, forcible rape as used here generally neans rape committed by means of physical force or threats, either actual or implied.

\section{I}

\section{What ReAlly Happens in Rape： AN Empirical ANalysis}

\section{A. The Magnitude of the Problem}

Froin 1960 to 1969 , reported rapes increased at roughly the same rate as other crimes, ${ }^{3}$ but in 1969 the rape rate surged ahead of other crimes agamst the person, and in two of the three following years it imcreased inarkedly. ${ }^{4}$ During the first six inonths of 1972, while both crimes against the person and against property either decreased or increased slightly, the rape rate increased substantially. ${ }^{5}$ This marked increase in rape reports is particularly surprising in view of the kind of information about the treatment of rape charges in the criminal justice system that has been widely disseminated since 1969. Media coverage of the treatment of rape complaints by the police and the courts has suggested the futility of making these complaints and has described in detail the harassment that rape victims who complain usually re-

2. CaL. Penal Code $§ 261$ (West 1970).

3. Conclusion based on computations derived from FEDERAL BuREAU OF INvestigation, UNIFORM CRIME REPORTS FOR THE UNITED StATES 61 (1971).

4. Federal Bureau of Investigation, Uniform Crime Reporting 1 (Jan.June, 1972). Annual percentage increases since 1968 for crimes against the person are:

$\begin{array}{lccc} & \begin{array}{c}\text { Increase from } \\ \text { Murder }\end{array} & \begin{array}{c}\text { Previous } \\ \text { Rear }\end{array} & \begin{array}{c}\text { (percent) } \\ \text { Aggravated Assault }\end{array} \\ 1969 & 6 & 17 & 9 \\ 1970 & 8 & 2 & 7 \\ 1971 & 11 & 11 & 10 \\ \text { Jan.-June, } & & & \\ 1972 & 1 & 14 & 6\end{array}$

5. Federal Bureau of Investigation, Uniform Crmm Reporting 1 (Jan.June, 1972). During the first six months of 1972 , robbery and auto theft reports decreased 4 percent, burglary increased 4 percent, and larceny increased 1 percent. Overall, Crime Index offenses increased 1 percent during this period. The 14 percent increase for rape offenses is remarkably inconsistent with the trend in other crimes. 
ceive at the hands of officials. ${ }^{6}$ This would seem to discourage, rather than encourage, women to report rapes. With the available information it simply is not possible to draw rehiable conclusions about the increase in reported rapes: it may stem from increased reporting, increased imcidences of the crime, or a combination of the two. ${ }^{7}$

In any event, however, it is clear that the number of reported rapes does not accurately reflect the actual incidence of forcible rape. Various studies have estimated that only 20 percent $^{8}$ of all forcible rapes are reported to police. One survey of 10,000 houseliolds found there were more than three and one-half times as many forcible rapes as had been reported to police, ${ }^{9}$ and this rate probably understates the actual figure. ${ }^{10}$ Another smaller survey showed that of 30 rape victims interviewed only two had reported the rapes to police, and many had never told anyone before. ${ }^{11}$ Various reasons have been advanced to explain why the victims of rape fail to report attacks. Parents may want to prevent publicity, further ordeal, and emotional imjury to a young victim. ${ }^{12}$ A victim may fear being accused of provocation, ac-

6. See, e.g., Griffin, Rape: The All-American Crime, RAMPARTS 26 (Sept. 1971); Sullivan, Rape and its Neglected Victims, San Francisco Chronicle and Examiner, April 9, 1972, California Living at 8; Stumbo, Rape: Does Justice Turn its Head?, L.A. Sunday Times, March 12, 1972, \& E, at 1.

7. There is some indication that when women can report rapes to a sympathetic investigator the report rate increases. Police in New York City have created the Rape Investigation and Analysis Section, staffed and directed by women. The director finds that rape victims are coming forward in unusual numbers now that they can report the attacks to women. NewSWEEK, Jan. 29, 1973, at 59. A second possibility is that changing attitudes about the crime, accompanied by heightened concern about rape that has been engendered by the wornen's movement, have reduced the social stigma and shame that formerly may have caused victims to be reluctant to report rapes. See text accompanying notes 8-13 infra. A third possibility is that hostility to women's increasing acquisition of freedom has led to an imcrease in forcible rape. This possibility is at least credible since a physical attack is the only way men can achieve dominance over wounen who otherwise refused to be dominated in traditional ways: the threat of rape can be consciously and unconsciously manipulated by men to ensure female subordination.

8. In California, it has been estimated that only 20 percent of all rapes are reported to police. State of California, Subcomm on Sex Crimes of the Assembly INTERIM Comm. on Judicial System and Judicial Process, Preliminary Report 26 (1950). Police in Minnesota have estimated that only 25 percent of all sex offenses come to their attention. Minnesota Department of Corrections, The Sex OfFENDER IN MINNESOTA 2 (1964).

9. National Opinion Research Center of the University of Chicago survey reported in PRESIDENT'S COMMISSION ON LAW ENFORCEMENT AND ADMINISTRATION OF Justice, The Challenge of Crime in a Free Society 23 (1967) [hereinafter cited as Challenge of Crime]. These figures place the reported rapes at approximately 27 percent of the actual rapes.

10. Id. at 21 .

11. A presently unpublished study by Diana Russell, Professor of Sociology, Mills College.

12. M. AMIR, Patterns in Forcible Rape 29 (1971) [hereinafter cited as AMIR, 
tive participation, or irresponsibility, or she may fear retaliation by the offender. ${ }^{13}$ She may experience shame or a desire to protect her reputation. She may also fear the reactions of her husband or parents. Whatever the reasons, the failure of victims to report rapes is itself a strong indication of the malfunctioning of rape laws and enforcement mechanisms.

\section{B. The Rapist and His Victim}

Rapists are generally "normal" men. Imprisoned rapists, who have been subjects of numerous psychological studies, appear to have basically normal personality profiles, although they have pronounced tendencies to be impulsive, aggressive, and violent. ${ }^{14}$ The overall picture is that of an average man with average intelligence. ${ }^{15}$ This conclusion is particularly significant simce only imprisoned rapists have been studied and, smce so few rapists are sentenced to prison, those few tend to be the more obviously dangerous offenders. Case studies of individual offenders tend to bear this out. ${ }^{16}$

The finding that rapists are normal men stands in sharp contrast to the nature of the rapes they commit. About half of all rapes are committed by men known to their victims, although the degree of acquaintance is usually slight. ${ }^{17}$ Yet, when there is a close relationship between rapist and victim, the violence used against the victim

Patterns]. Amir's study is by far the most exhaustive statistical analysis of rape available. He studied 646 rapes occurring in 1958 and 1960 in Philadelphia. 646 victims and 1292 offenders were involved. Police files furnished the basis for the study.

13. Id.

14. A survey of all studies on the clinical profile of sex offenders concludes that rapists "do not constitute a unique clinical or psychopathological type; nor are they as a group invariably more disturbed than the control groups to which they are compared." In these studies, the rapist was found to have "a normal personality and normal sexual instincts as measured by his choice of victim for sexual gratification." AMIR, PatTerns, supra note 12, at 314. One study, however, showed that 50 of 102 imprisoned sex offenders studied were either "predisposed to crimes of violence," and thus required a maximum security prison, or were a continuing threat to the public, although not violent. Many of these sex offenders were not rapists. State of New York, Report on the Study of 102 Sex Offenders at Sing Sing Prison 15, 17-19 (1950) [hereinafter cited as Sing Sing STUdY.]

15. Sing Sing Study, supra note 14, at 14. AMir, PatTerns, supra note 12, concludes also that inost rapists are single, [id. at 61] between the ages of 15 and 24, [id. at 52] and of poverty classes, [id. at 70] where there is considerable access to women for consensual sexual contact, [id. at 73]. There is some evidence that rapists have a very high rate of venereal infection. Sex offenders in Michigan prisons average 112 VD cases per 1,000 , while the general population average is 5.4 per 1,000 . Michigan, Governor's Study Commission on the Deviated Criminal Sex OfFENDER, REPORT 29 (1951).

16. See generally Sing Sing STUDY, supra note 14.

17. AMIR, PatTerns, supra note 12, at 234. Amir shows the following relationships in his study: 
tends to be greater. ${ }^{18}$ Furthermore, few rapes are spontaneous: over 80 percent are entirely or partially planned. ${ }^{19}$ Over two-fifths of all forcible rapes are "gang" rapes, involving two or more offenders and a single victim. ${ }^{20}$ Sexual humiliation, including forced fellatio, cunnilingus, sodomy, and repeated intercourse, occurs in over a quarter of all reported cases. ${ }^{21}$ Physical force is used in 85 percent of all reported cases; ${ }^{22}$ brutal beatings occur in one-fifth of the cases; ${ }^{23}$ a fourth

$\begin{array}{lr} & \text { percent } \\ \text { stranger } & 42.3 \\ \text { stranger but general knowledge } & 9.6 \\ \text { acquaintance } & 14.4 \\ \text { close neighbor } & 19.3 \\ \text { close friend or boyfriend } & 6.0 \\ \text { family friend } & 5.3 \\ \text { relative } & 2.5 \\ \text { no information } & .6\end{array}$

One study reports that for all sex offenders studied, including rapists, only 37.6 percent had no prior relationship with their victims. However, these figures included a nnmber of men couvicted of incest. Minnesota Department of Corrections, The SEX OFFENDER IN MINNESOTA 18 (1964). Several studies have reported that rape is perpetrated by a stranger in about half of all cases. NATIONAL COMMISSION ON THE Causes and Prevention of Violence, final Report: To Establish Justice To Ensure Domestic Tranquiltty 25 (1969); Michigan, Governor's Study Commission on Deviate Crminal Sex Offender, Report 75 (1951). The District of Columbia Crime Commission found that 36 percent of 224 assailants studied were strangers to their victims and another 7 percent were known only by sight. 14 percent were relatives, family friends, or boyfriends, and 39 percent were acquaintances or neighbors. Challenge of Crime, supra note 9, at 40 . A study of only 100 cases showed the offenders to be strangers in two-thirds of the cases. Schiff, Statistical Features of Rape, 14 J. For. SCI. 102, 105 (1969).

18. AMIR, PATTERNS, supra note 12 , at 245 : "[N]eighbors and acquaintances are the most potentially dangerous people as far as brutal rape is concerned." Amir also concludes:

In general, the analysis of the interpersonal relations between victin and of-

fender lent support to those who reject the myth of the offender who attacks a victim unknown to him. But equally rejected is the notion that rape is generally an affair between, or a result of, intimate relations betweeu victims and offenders.

Amir, Forcible Rape, 31 FED. Prob. 51, 57 (March 1967).

19. AMIR, PATTERns, supra note 12, at 142. Of 646 rapes, 71 percent were completely planned, 11 percent were partially planned, and 16 percent were spontaneous.

20. AMIR, PATteRNS, supra note 12 , at 55.43 percent of the rapes studied by Amir were multiple. Another study, with a sample of 100 consecutive rapes in one county, showed 42 percent of the cases to involve inultiple rapists (anywhere froin 2 to 10 men). Schiff, Statistical Features of Rape, supra note 17, at 105. California provides for a sentence of five years to life for rape committed while "acting in concert with another persou by force or violence." CAL. PEN. CODE $\$ 264.1$ (West 1970).

21. AMIR, Patterns, supra note 12, at 159.

22. AMm, PAtrerns, supra note 12, at 54-55. Another study shows physical signs of trauma in 38 percent of the cases. However, the figures do not take into account how much time has elapsed between the rape and the medical examination on which the fignres are based. Schiff, Statistical Features of Rape, supra note 17, at 107.

23. AMIR, Patterns, supra note 12, at 155. Amir reports the following figures for all reported cases: 
of the victims are attacked with dangerous weapons. ${ }^{24}$ Over one-half of the victims are submissive during the rape, ${ }^{25}$ not a surprising figure in view of the general use of physical force and threats by rapists.

Overall, the picture of the relationship between the rapist and his victim shows rape to be a brutal, violent event in which the rapist has as his aim not only forcible sexual gratification, but also subjugation and humiliation of the victim. Rape, then, is not the product of uncontrollable sexual urges that are unleashed spontaneously. But neither are most rapists sex maniacs; research indicates that most rapists are psychologically normal and there is no foundation for the prevalent notion that they usually are psychotics. As subsequent sections show, however, these misconceptions have helped shape legal attitudes about rape.

\section{II}

\section{INDIVIDUAL AND SOCIAL INTERESTS Protected BY RAPE LAWS}

In order to place the phenomenon of rape in its legal context, it is also necessary to understand the conceptual framework in which rape laws exist. Here the focal question is: Who or what do rape laws protect? Legal writers analyzing rape laws have concluded that rape laws protect male interests: rape laws bolster, and in turn are bolstered by, "a inasculine pride in the exclusive possession of a sexual object,",26 they focus a male's aggression, based on fear of losing his sexual partner, against rapists rather than against innocent competitors, ${ }^{27}$ rape laws help protect the male from any "decrease in the 'value'

$\begin{array}{ll}\text { no force used } & 14.9 \% \\ \text { roughness } & 28.5 \% \\ \text { nonbrutal beating } & 24.7 \% \\ \text { brutal beating - } & \\ \text { choking } & \end{array}$

24. The District of Columbia Crime Commission survey of 151 cases, as reported in Challenge of Crume, supra note 9, at 19. This survey also showed that one percent of forcible rapes ended in homicide.

25. AMrR, PATTERNs, supra note 12 , at 166 . About one-fifth of the victims in this study put up a strong physical fight, and another quarter actively resisted in some other way, by screaming for example. Amir also found that younger victims were less likely to resist their attackers, and rape victims tend to be young. Id. at 167 . 20 percent of the victims in his study were between the ages of 10 and 14 , and 25 percent were between 15 and 19. Id. at 52 . Another study found that 47 percent of the victims were between the ages of 10 and 19, the youngest being six and the oldest 57. The most frequently reported age was 14. Schiff, Statistical Features of Rape, supra note 17 , at 104.

26. Comment, Forcible and Statutory Rape: An Exploration of the Operation and Objectives of the Consent Standard, 62 YALE L.J. 55, 72 (1952) [hereinafter cited as Consent Standard].

27. Comment, The Resistance Standard in Rape Legislation, 18 STAN. L. REv. 680, 684 (1966), citing with approval Consent Standard, supra note 26, at 72. 
of his sexual 'possession'," which results from forcible violation. ${ }^{28}$ However accurate these conclusions are, it is interesting that these analyses have not focused on a woman's physical integrity, peace of mind, or freedom of movement without fear of sexual attack as fundamental values to be protected by rape laws. ${ }^{29}$ The male values that are protected by rape laws are easily translated into societal values. This may explain why so many countries and some states classify rape as a crime against society, not as a crime against the person. ${ }^{30}$ California, for instance, categorizes rape along with gambling, indecent exposure, horse racing and abortion as crimes against the person and against public decency and good morals. ${ }^{31}$

The statutory rape laws offer a further indication that rape laws seek to protect male interests. Statutory rape laws ostensibly protect girls too young ${ }^{32}$ to make an intelligent decision when hazards such as pregnancy and venereal disease are involved. This justification might be convincing if laws protected only the very young, but applied to a 17 year old woman it appears more likely to reflect moral value judgments. Because only the sexual activity of young women, not young men, is regulated, it may be argued that the value served by statutory rape laws is the preservation of the "market value" of virgimal young women as potential brides, rather than the protection of the naive from sexual exploitation. A young woman's right to choose whether to be chaste or sexually active appears to have been given litthe consideration in the formulation of statutory rape laws. Her consent to sexual intercourse is, by law, irrelevant to whether that intercourse is or is not rape..$^{33}$

The legal impossibility of rape of a wife by her husband is another indication that rape laws are not aimed at protecting women from sexual assault. If the laws were designed to protect women, this

28. Consent Standard, supra note 26 , at 73. The writer points out that using words like "ravaged" and "despoiled" to describe the rape victim reflects the idea of a stain attaching to the woman's body and the subsequent loss of her value to her male possessor.

29. CaL. Penal CODE $\S 263$ (West 1970), however, does state that "the essential guilt of rape consists in the outrage to the person and feelings of the female. Any sexual penetration, however slight, is sufficient to complete the crime."

30. France classifies rape as a "Moral Offense." French Penal Code, Section IV, Article 332 (Amcrican Series of Foreign Penal Codes, no. 1, 1960). Norway classifies rape under "Felomies Against Public Morals." Norwegian Penal Code, Chapter 19, Section 192 (American Series of Foreign Penal Codes, no. 3, 1961).

31. Cal. Penal Code title 9 (West 1970).

32. CaL. Penal Code $\S 261$ (West 1970). The age of consent was changed from ten to 14 years in 1889 , increased to 16 years in 1897 , and increased to 18 years in 1913. The age of consent in Tennessee is 21. TENN. CODE ANN. $\$ 39-$ 3706 (1955).

33. People v. Johns, 173 Cal. App. 2d 38, 343 P.2d 92 (2nd Dist. 1959). 
exception would make no sense. There are, of course, conceptual difficulties mvolved in making rape a crime between husband and wife. $^{34}$ But if a woman suffers no less pain, humiliation, or fear from forcible sexual penetration by her husband than by a relative, a boyfriend, or a stranger, the difference is not great enough to warrant the total imsulation of the former but not the latter from legal sanction. One writer has recognized that women need protection from forcible sexual encounters with their husbands. He concludes, however, that only the law of battery lends itself to that use-and even its use presents difficulties. Rather than suggesting a means to protect the interests of wives against forcible sex with their husbands, this commentator concludes that only after an absolute and final divorce decree should a husband be prosecuted for rape of his wife. Such a rule, he argues, is necessary to encourage reconciliation between the spouses during the interim waiting period. ${ }^{35}$

Rape laws, and legal discussions of those laws, are also shaped by the fear of the stereotypical maniac rapist who leaps from the bush with knife in hand. The fear of the psychopathic rapist, and the high value of the male interests threatened by rape (e.g., the "despoiling of his goods") have no doubt combined to produce the severe sentences that the law stands ready to impose for rape. A number of states provide for death as a possible or inandatory penalty for rape, ${ }^{36}$ although Furman v. Georgia ${ }^{37}$ now prevents execution under some of these statutes. Other states provide for sentences up to life imprisonment. Coinparisons with crimes of coinparable magmtude show that rape carries very high penalties. Conviction for assault with a deadly weapon or with force likely to produce great bodily injury carries a minimum sentence of six months in California. ${ }^{38}$ Yet

34. The primary conceptual barrier to making forcible sexual intercourse between husband and wife "rape" is the consent standard. This doctrine is based on the premises that consent to sexual relations is inseparable from the marriage relation itself and that consent is a total defense to a charge of rape. Since a woman is, theoretically, consenting to all sexual intercourse with her husband as long as she remains married, rape is not possible between marital partners. The other barriers to defining an offense by a husband against his wife as "rape" are largely administrative-problems of proof and evidence as well as opportunity for malicious prosecution.

35. See Comment, Rape and Battery Between Husband and Wife, 6 StAN. L. Rev. $719,724-25$.

36. See, e.g., 14 ALA. Code $\$ 395$ (1959); 16 NEv. REv. Stat. § 200.363 (1968); 21 OkLA. STAT. ANN. $\$ 1115$ (1972).

37. Furman v. Georgia, 408 U.S. 238 (1972), found the death penalty in some instances to be unconstitutional. At least two states with mandatory death penalties have held, following Furman, that a "mercy" proviso giving the jury discretion to confer a life sentence instead of death, is unconstitutional. Such holdings have left the mandatory death penalties intact. State v. Dickerson, 41 U.S.L.W. 2271 (Del. Nov. 1, 1972); State v. Waddell, 41 U.S.L.W. 2398 (N. Car. Jan. 18, 1973).

38. Cal. Penal Code $\$ 245$ (West 1972 Supp.). 
rape under the same circumstances carries a minimum sentence of 3 years. $^{39}$ Furthermore, in California, sodomy is punished by a one year to life sentence whether or not force is used..$^{40}$

III

Investigation and Prosecution: The Impediments to Conviction

Although rapes tend to be both violent and planned, ${ }^{41}$ very few apprehended rapists are ever charged with and convicted of rape; fewer yet are committed to institutions. ${ }^{42}$ In California, there is a higher acquittal rate for rape than for any other felony. ${ }^{43}$ Regional studies show that about 10 percent of those originally charged with rape go to prison. ${ }^{44}$ The reasons for this failure to charge and convict are clear:

39. Cax. Penax CoDE $\S 264$ (West 1970). If great bodily injury accompanies the rape, the rapist is subject to a fifteen year minimum senteuce. Otherwise forcible rape is punished by a 3 year to life sentence.

40. Cal. Penax Code $\$ 286$ (West 1970).

41. See text accompanying notes 19-24 supra.

42. National figures show that in 1970,56 percent of all rape complaints ended in arrests. 62 percent of those arrested were prosecuted. 36 percent of those prosecuted were convicted of rape; 18 percent were convicted of lesser offenses; 46 percent ended in acquittals or dismissals due to prosecutorial problems (as compared to 29 percent acquittal or dismissal rate for all crimes). Federal Bureau of INvestigation, UNIFORM CRIME REPORTS FOR THE UNTTED States (1970) at 32 and 36. Assuming that those rape complaints are valid (F.B.I. figures exclude "unfounded" rapes) a man who rapes a woman who reports the rape to police has roughly seven chances out of eight of walking away without any convictiou. Assuming only one woman in five reports the rape, his chances increase to 39 out of 40 . If these figures take into account the high percentage of those who receive probation or suspended senteuces, his chances of escaping incarceration are in the vicinity of 98 to 99 out of 100 . Forcible rape has a lower conviction rate than any other crime histed in the UNIFORM CRIME REPORT. Id. at 36.

Jury attitudes uo doubt contribute to these astonishing figures. Walter H. Giubbini, Chief Assistant District Attorney of San Francisco, states that it is extremely difficult to get a conviction for rape, partly because of the distrust jurors have of rape victims:

I've heard both men and women, while being examined to see if they were suitable jurors, say that they didn't believe a girl could be raped-under any condition. Obviously, they are not accepted for jury duty, but I suspect that there are others that serve who believe this but might not say it.

Sullivan, Rape and the Neglected Victims, supra note 6, at 9.

43. Bureau op Criminal Statistics, California State Department of Justice, Crmme \& Delineuency in Carifornia 102 (1967). These figures show that 14.2 percent were acquitted and another 9.2 percent were dismissed. 54.2 percent were convicted on a guilty plea and only 29.9 percent were convicted by trial. Of those convicted, 15.2 percent went to prison, 59.6 percent received probation, 13.7 percent went to jail, and 11.5 percent received other dispositions such as fines or civil commitment. These figures all mclude statutory rape. By way of comparison, of those convicted of robbery, 33.2 percent received probation while 43.2 percent went to prison and 9.7 percent went to jail. Id. at 117 .

44. A study of 1219 men charged with rape in New York City in 1948 showed that 630 were acquitted or had charges dismissed. In addition, there were 15 men 
legal and social attitudes about rape have produced a network of formal and informal restraints on the actions of police, prosecutors, judges, and juries that hinder prosecutions for forcible rape.

\section{A. Investigation of Rape Complaints}

\section{Unfounding of Rape Complaints}

About one-fifth of the rape complaints received by police are "unfounded" after they are made. ${ }^{45}$ This term is a technical one, meaning only that police, for various reasons, have decided not to advise prosecution. It does not imply that the woman's report of the rape is inaccurate. The unfortunate ambiguity of the term and the high rate of "unfounding" have perhaps contributed to the myth that women make many false rape coinplaints.

Most coinplaints subsequently "unfounded" by police involve at least one of the following factors: (1) evidence that the victim was intoxicated;" ${ }^{46}$ (2) delay in reporting by the victim; ${ }^{47}$ (3) lack of physical condition supporting the allegation; ${ }^{48}$ (4) refusal to submit to a medical examination; ${ }^{49}(5)$ the previous relationship of the victim and the offender; ${ }^{50}$ and (6) the use of a weapon without accompanying battery. ${ }^{51}$ Police also "unfound" complaints because victims fail

charged with other crimes but convicted of rape. Out of the total of 138 convicted of rape, 95 were sent to jail or prison, 28 were placed on probation, 11 received suspended sentences and 4 were fined. Sing Sing STUdy, supra note 14, at 31. A Michigan study showed that out of every 10 sex crime complaints, in 6 an accused is identified, in 3 warrants are issued for which 2 convictions result, and 1 goes to prison or jail, while 1 is placed on probation. Michigan, Governor's STUdy COMMISSToN ON THB Deviated Criminal Sex OfFender, Report 73 (1951). In the California reported figures, supra note 43, about 11 percent of those charged with rape went to prison.

45. The FBI reports a national "unfounding" average of 18 percent for rape. FEderal BUREAU of INVEstigation, UNIForm CRIME REPORTS 14 (1971). The Philadelphia Police Department unfounded 21 percent of the rape complaints received in the latter half of 1966. Note, Police Discretion and the Judgment that a Crime Has Been Committed-Rape in Philadelphia, 17 U. PA. L. REv. 277, 280 (1968) [hereinafter cited as Police Discretion]. Schiff reports that in his study 19 percent of all rapes were unfounded by police. Schiff, Statistical Features of Rape, supra note 17, at 108.

46. Police Discretion, supra note 45 , at 292.82 percent of those complaints where the victim had been drinking were unfounded.

47. Id. at $282,285$.

48. Id. at 287.

49. Id. at 289 . Fifty-six percent of those complaints where victims rcfused a medical examination were unfounded.

50. Id. at 291. When the offender was the victim's date, 43 pcrcent of the coinplaints were unfounded; when a friend, 19 percent were unfounded; when an acquaintance, 28 percent were unfounded; and when a stranger, 18 percent were unfounded. founded.

51. Id. at 298. No cases involving a weapon, threat, and battery were un. 
to preserve necessary physical evidence (for instance, they may douche before reporting the crime) or because victims are too emotionally upset, too young, too afraid, or too embarrassed to cooperate with the ordeal of the police investigation. ${ }^{52}$ Most of these factors are not relevant to whether or not a rape has been committed. They are, however, relevant to the chances of obtaining a conviction in court. For that reason, complaints presenting these prosecutorial disadvantages are "unfounded."

Victim precipitation ${ }^{53}$ inay weaken an otherwise strong case against a rapist and lead police to "unfound" the complaint. Victim precipitation is a conclusory label applied to cases where the victim either retracts from an initial agreement to have sexual relations or enters into a "vulnerable" situation. Police commonly refuse to proceed with a complaint involving victim precipitation since such a complaint has little chance of leading to a conviction. ${ }^{54}$ As a post facto conclusion, however, a finding of victim precipitation depends upon the perspective of the largely male police, prosecutors, and judges who appraise the case. The concept of victim precipitation hinges primarily on inale definitions of expressed or implied consent to engage in sexual relations, and is shaped by traditional restrictive stereotypes of woinen. Thus, hitchhiking and walking alone at might in a rough neighborhood may be considered behavior encouraging a sexual attack. $^{.55}$ This view of what a man can assume to be a sexual invitatoin is unreasonable, but is so well engrained in society that women often accept it as well. As a result, a woinan may react to being raped with considerable guilt and refuse to report the attack. A woman hitchhiker may later feel that she encouraged the rape simply by accepting a ride. Yet, when the female hitchhiker first sets out to get a ride, she normally is not expecting-or hoping for-a sexual encounter. A woman should not be made to feel guilty for acts that do not involve express sexual invitation, nor should she be denied the right to change her mind. In its failure to accord any consideration to the

52. State of Californta, Subcomm. on Sex Crimes of the Assembly INternm Comm. on Judicial System and Judicial Process, Preliminary Report 73 (1950).

53. AMIR, Patterns, supra note 12, at 266. Amir concludes that 19 percent of the cases in his study are to be so classified.

54. It should be noted that victim-precipitated cases involve greater danger to the victim than do cases where there is no victim-precipitation. In Amir's Study, 92.7 percent of these victims were also victims of physical force, as compared with 83.4 percent of the non-victim-precipitated rapes. AMR, PATTERNs, supra note 12, at 269. These victims were three times more likely to be victims of sexual humiliation. Id. at 270. Although the median age of non-precipitating victims was higher than that of precipitating victims, a substantially higher proportion of the latter were between the ages of 15 and 19 . Id. at 271.

55. Schiff, Statistical Features of Rape, supra note 17, at 105. 
woman victim's intentions, victim precipitation becomes nothing more than a male view of the circumstances leading up to the incident.

Certainly many complaints "unfounded" by police would, as a practical matter, result in acquittals were they brought to court. This is not to say, however, that most "unfounded" complaints are false or that they involve victim precipitation, although this may be the contention of the police. Rather, the high rate of "unfounding" may instead indicate that the rape laws as they are now structured are overly solicitous to the defendant and overly suspicious of the complainant. If laws were structured so as to facilitate rather than prevent the conviction of rapists, the "unfounding" rate by police would alnost certainly dimimish.

\section{Failure to Use Scientific Investigation}

A recent study found that although medical examinations were obtained from 60 percent of the rape victins, the examination results were actually used in ouly 18 percent of the complaints to help determine whether or not to "unfound." The police insisted that a medical examination be performed, discrediting the woman's veracity if she refused, yet they made little use of the evidence derived from the examination when determining whether to press charges.

Thirty years ago a police medical examimer stated that it was possible to reconstruct most rapes by means of scientific evidence, ${ }^{57}$ and since then investigative techniques have been greatly refined. Neutron activation analysis, by estabishing with a high degree of probability that hairs or other materials found in separate places have a common origin, can help exonerate a defendant or establish his presence at the scene of the rape. ${ }^{58}$ The victim's clothing can be examined microscopically and under fluorescent light to establish facts about the scene of the offense. Teeth marks, scratclies, and bruises can be located; lesions on or about the introitus and the condition of the hymen can be noted. ${ }^{59}$ Tests for venereal disease can be performed. Washings taken from the vulva, perineum, and vaginal vault can give rise to strong evidence of recent intercourse. ${ }^{.0}$ Similarly, the accused's clothing and person can be examined. Washings taken from the ac-

56. Police Discretion, supra note $45,310-11$.

57. Rife, Scientific Evidence in Rape Cases, 31 J. CRIM. L. \& Crm. 232, 235 (1940): "We believe that if the police examiner utilizes every means possible, especially the microscopic examination of all clothing and secretions of both parties involved, the crime of rape may be reconstructed rather completely."

58. See Comment, The Evidentiary Uses of Neutron Activation Analysis, 59 CaLIF. L. Rev. 997 (1971).

59. Rife, Scientific Evidence in Rape Cases, supra note 57, at 232.

60. Id. 
cused's penis can determine that he has recently engaged in intercourse. $^{61}$ Fingernail scrapings froin both parties are extremely valuable in establishing the identity of the rapist and the degree of the victim's resistance. ${ }^{62}$ Similarly to blood groups, ${ }^{63}$ semen can be typed in order to prove whether a particular suspect could have committed the rape.

Although these tests cannot always prove that a rape occurred, and although women sometimes delay reporting a rape so that this type of investigation cannot be performed, a thorough investigation by a medical examiner often can prove not only that intercourse has occurred but also the probability that there has been a rape and the probability that the accused is the rapist. Yet these scientific tests are seldoin employed. ${ }^{64}$ In view of the prevalent concern about false rape reports, it is curious that practical nethods of combatting such false reports are not used niore frequently.

\section{B. Obstacles to Rape Convictions}

The rape laws and the literature concerning them have been dominated by fears that false rape charges might result in the convictions of innocent men. The false complaint is feared more in rape cases than in other crimes because of the basic assumptions that many wornen are either amoral or hostile to $\operatorname{men}^{65}$ and that women can induce rape convictions solely by virtue of fabricated reports. The commentators, however, consistently have failed to document or closely analyze these assumptions. Nevertheless, these fears have produced and sustained laws and attitudes that seek to protect the innocent from an unjust rape conviction, rather than to protect woinen from rape.

Concomitant with the assumption that woinen make false rape

61. Id. at 232-33. See also Thomas and Van Hecke, The Demonstration of Recent Sexual Intercourse in the Male by the Lugol Method, 3 MED. ScI. \& LAW 169 (1963). There are vaginal parasites that are never found alive on and under the male's foreskin unless the male lias recently engaged in intercourse. Rife, Scientific Evidence in Rape Cases, supra note 57, at 233.

62. Id. at 234. See also Bornstein, The El Paso County Program for the Medical Investigation of Sexual Offenses, 3 J. For. Scr. 123, 125-26 (1958). (1965).

63. Schultz, How Many More Victims? Society and the Sex Criminal 194

64. Comment, Consent Standard, supra note 26, at 81; Police Discretion, supra note 45 , at 316 .

65. See Note, The Rape Corroboration Requirement: Repeal Not Reform, 81 YALE L.J. 1365, 1373 (1972). The motives seen as prompting false accusations of rape are: slaine, protection of an innocent party, blackmail purposes, hatred, revenge, and notoriety. The writer points out that to whatever extent these motives exist they are outweigled by the disincentives to report rapes and by the ease with which modern criminal investigation and traditional legal rules can uncover them. Id. at 137475. 
charges is the belief that it is difficult to defend against a charge of rape. Lord Chief Justice Hale's old saw that rape is a charge "easily to be made and hard to be proved, and harder to be defended"0o expresses that partnership of fears and has been quoted by virtually every legal writer who has discussed rape. It is further preserved in California jury instructions. ${ }^{67}$ The notion that it is difficult to defend against a rape charge originates in the belief that, since there is seldoin any corroborative evidence in rape cases, ${ }^{88}$ the outcoine hinges on oath against oath. Also, it is believed that juries are inordinately sympathetic with rape victims. ${ }^{69}$ Actually, jury sympathy often may be with the defendant. ${ }^{70}$

Another attitude affecting the conviction rate is the pervasive belief that women like to be raped. ${ }^{71}$ Psychological literature is a prime source of this myth. Concurrently, there is a feeling that inen who rape are not responsible for their acts since they are victims of "uncontrollable emotions and passions, unexplainable urges, and fierce de-

66. 1 M. Hale, The History of the Pleas of the Crown 635 (1778).

67. Committee on Standard JuRy Instructions, CrtminaI, of the Superior Court of los angeles County, California, California Jury instructions, CRIMINAL 10.22 at 327 (3rd rev. ed. 1970) [hereinafter cited as CAIJIC]:

A charge such as that made against the defendant in this case is one which is easily made and, once made, difficult to defend against, even if the person accused is innocent.

Therefore, the law requires that you examine the testimony of the female person named in the information with caution.

68. Comment on Recent Cases, 43 Iowa L. Rev. 650, 651 (1958).

69. Puttkamer, Consent in Rape, 45 ILL. L. Rev. 410, 422 (1925); Comment, The Corroboration Rule and Crimes Accompanying a Rape, 118 U. PA. L. REv. 458, 460 (1970).

70. See note 42, supra. A deputy district attorney for Los Angeles county related a recent case in which a 19 year old secretary was raped in a parking lot in daylight. A witness to the rape made a positive identification. The district attorney commented that "all rape cases are hard to prosecute, of course, but this one was so solid." Yet the jury acquitted the accused. One juror stated: "I just could'n't believe that a boy whose girlfriend was as pretty as the one who came into court to testify would have even wanted to rape such a plain-looking girl." The juror's inability to imagine the possibility of such a rape is hardly warranted: although the evidence could not be admitted into court, the defendant had been acquitted, just nine days before the victim was raped, on a charge of assault with intent to rape. That time, he lad a gun. Los Angeles Times, March 12, 1972, Sec. E, at 1, col. 3-8.

71. See Jenkins, The Making of a Sex Offender, 30 Focus 129, 130-31 (1951); Note, The Resistance Standard in Rape Legislation, 18 STAN. L. R51. 680, 682 (1966). A writer for the Los Angeles Times placed this concept in historical perspective:

Ultimately, it is still the burden of rape victims to overcome a tradition of myth and bias which has historically celebrated rape in song and poem and classical painting, produced some of modern mankind's raunchiest locker rooin jokes, equated rapists with red-blooded he-men, victims with seductresses and, in general assumed time and again that there actually is no such thing as rape-that the woman must have enjoyed being raped as much as he enjoyed raping her because, after all, isn't that the natural biological order of things, sooner or later?

Los Angeles Times, March 12, 1972, Sec. E, at 1, col. 7-8. 
sires which can be considered impossible to control once they have been aroused."72 Once aroused, the belief goes, rape is the natural result if the woman is not willing to satisfy the appetite she has created. A combimation of the notions that women enjoy assaults and that men are subject to uncontrollable sexual passions aroused by women diminishes the amount of blameworthiness society is willing to ascribe to rapists. ${ }^{73}$ As a result, rape is redefined as an act that is viewed as scarcely criminal. Thus it is not surprising that psychologists, generally men, declare rapists to be normal. ${ }^{74}$

\section{Psychiatric Examinations of Victims}

Some commentators press for a psychiatric examination of the victim as a means of identifying the fabricated complaint. ${ }^{75}$ One writer stated that false accusations often are made by mentally disturbed women; thus if the state offers neither corroborating evidence nor a psychiatric report, "it would not be assumed that the witness is a normal individual, notwithstanding the persuasiveness of her testimony." An Another writer stated that sex complaints are easily made, therefore psychiatric examination of alleged victims is recommended. ${ }^{77}$ Neither offered evidence either for the proposition that unsubstantiated or false charges are frequently brought or for the assumption that psychiatric examinations can determine the facts of the case or the veracity of the victim's testimony. A third writer recognized that such an examination will not produce reliable results if the victim submits to it unwillingly, yet he still concluded that she should be forced to submit

72. McLaughlin, The Sex Offender, 29 PoLICE CHIEF 26, 28 (Dec. 1962).

73. One writer observed some 1500 delinquency petition hearings before a metropolitan juvenile court and found that the judge refused to punish any form of sexual behavior on the part of boys, even the most bizarre, except by probationary status. He regarded girls as the "cause" of the boys' sexual deviation in all cases of coition involving an adolescent couple and refused to hear any complaints by the girl or her fanily; she was regarded as a prostitute. This writer also observed a religious fundamentahist judge in a southern county jurisdiction who showed the opposite pattern; the girl was "invariably seeu as victimized by the boy." Reiss, Sex Offenses: The Marginal Status of the Adolescent, 25 LAW \& CONTEMP. ProB. 309, 316 (1960).

74. See note 14 supra and accompanying text.

75. The admissibility of psychiatric testimony to impeach a witness is an unsettled question. The rule excluding such evidence was established in State v. Driver, 88 W. Va. 497, 107 S.E. 189 (1921) (a rape case) but the court in United States v. Hiss, 88 F. Supp. 559 (S.D.N.Y. 1950), aff'd on other grounds, 185 F.2d 822 (2d Cir. 1951), cert. denied, 340 U.S. 948 (1951) held such psychiatric evidence admissible. In any case, it is a long jump from permitting the use of such evidence, already available, to forcing a witness to submit to a psychiatric examination purely in hopes of obtaining evidence for impeachment.

76. Note, Recent Cases: Psychiatric Aid in Evaluating the Credibility of a Prosecuting Witness Charging Rape, 26 IND. L.J. 98, 102 (1950).

77. Comment, Evidence, Sex Offenses, and Credibility of Complaining Witness, 43 IOWA L. REv, 650, 651 (1958). 
to one if the issue of her mental condition is raised. ${ }^{78}$ An English writer, conceding the unreliability of psychiatric examinations, suggested that lie detector tests for victims be required, ${ }^{70}$ since sex cases are prone to deliberately false charges resulting from neurosis, fantasy, jealousy, spite, or the woinan's refusal to admit that she consented to the sexual relations. ${ }^{80}$ Yet no evidence supporting these underlying assumptions was provided.

In California, the supreme court has held to a middle course on the issue of psychiatric examination of victims, vesting discretion in the trial judge to order such an examination if little corroboration supports the charge and if the defense raises the issue of the victim's mental condition affecting her veracity. ${ }^{81}$ The judge may comment to the jury on the victim's refusal to undergo exammation. ${ }^{82}$ Although a psychiatrist can tell if his patient is subject to sexual delusions, he cannot thereby prove she has not been raped. ${ }^{83}$ Apparently no firm legal definition of delusion exists since legal writers interchange fantasy and delusion. Certainly most woinen and most men have sexual fantasies, but that is unrelated to a person's veracity. Even if delusion is carefully restricted to describe only persons with serious mental disorders, a grave problem remains. If a psychiatrist's statement that a woman is subject to delusions creates a presumption that she has not been raped, then the law will, in effect, license the rape of inentallydisordered women. Women patients in mental hospitals, for example, would have little protection froin sexual assaults.

Mandatory psychiatric examination of victims would inflict additional trauma upon the coinplaining victim, would further discourage woinen from reporting sexual assaults, and would increase the tendency to place the victim rather than the accused on trial-while faihing to achieve its intended purpose of establishing the victim's veracity.

\section{The Consent Standard and Credibility of the Victim}

Attacks on the "consent" standard, which defines rape in terms of the woinan's frame of mind, have also been based on the fear of con-

78. Note, Criminal Law-Psychiatric Examiniation of the Prosecutrix in Rape Case, 45 N.C. I. REv. 234, 238-40 (1966).

79. Williams, Corroboration-Sexual Cases, 1962 CRIM. L. REv., 662, 664.

80. Id. at 662 .

81. Ballard v. Superior Court, 64 Cal. 2d 159, 410 P.2d 838, 49 Cal. Rptr. 302 (1966). See Note, Criminal Law-Psychiatric Examiniation of Prosecutrix in Rape Case, 45 N.C. L. REv. 234 (1966).

82. Ballard v. Superior Court, 64 Cal. 2d 159, 177, 410 P.2d 838, 849, 49 Cal. Rptr. 302, 313 (1966).

83. Note, Corroborating Charges of Rape, 67 Colum. L. Rev. 1137, 1143 (1965); Slovenko, Witnesses, Psychiatry and the Credibility of Testimony, 19 U. FLA. L. REV. 1, 20 (1966). 
victing innocent men of rape. Psychological theorizing, states one writer, indicates the unreliability of a woman's account of a rape, so "nothing should be left to the conceivably unreasonable opinion of the alleged victim," the woman's opinion is often distorted. ${ }^{84} \mathrm{He}$ suggests that a "resistance" standard replace the consent standard. Another writer, also suspicious of the consent standard, believes that the complaining witness is "compelled by many motives of self-interest" to assert that the sexual act was rape. ${ }^{85} \mathrm{He}$ believes that false charges can be constructed with exceptional ease and are "extremely likely to succeed." these beliefs.

One precaution taken on behalf of the accused is the well settled rule that evidence of another sex crime committed by the defendant at a different time and against another person, having no connection with the crime charged, is not admissible unless to show, for instance, the identification of the accused. ${ }^{87}$ Although evidence of past sexual acts cannot be used to impeach the male, however, it is a general rule that evidence of the "unchastity" of the female is admissible for the purpose of showing the probability of her consent to the act of intercourse. ${ }^{88}$ It is considered more probable that an "unchaste" woman will consent more readily to intercourse than a chaste woman. "Unchastity" simply means, of course, that the woman, if unmarried, is not a virgin. California incorporates this presumption into a mandatory cautionary instruction which states that the jury may infer that a woman who has once consented to sexual intercourse would be more likely to consent again, and that the evidence of her "unchastity" goes both to the issue of her consent and to her credibility ${ }^{89}$ Moreover, defendant may show that the prosecutrix has engaged in intercourse with him before, thus raising a presumption of her consent to the sexual act charged.90 Thus, legally, a man's previous sexual attacks, even if criminal, are of no relevance to his credibilty, but once a woman has had sexual relations with one man, a legal presumption

84. Comment, The Resistance Standard in Rape Legislation, 18 STAN. L. REv. 680,683 (1966).

85. Puttkammer, Consent in Rape, 19 ILL. L. REv. 410, 421 (1925).

86. Id. at 422 .

87. People v. Paxton, 255 Cal. App. 2d 62, 62 Cal. Rptr. 770 (2d Dist. 1967). See generally 44 AM. JUR. Rape $\$ 79$ (1942).

88. People v. Merrill, 104 Cal. App. 2d 257, 231 P.2d 573 (1st Dist. 1951); People v. Hurlburt, 166 Cal. App. 2d 334, 333 P.2d 82 (1st Dist. 1958). But see People v. Collins, 25 III. 2d 302, 186 N.E.2d 30 (1962). See generally 44 AM. JUR. Rape 90 (1942).

89. CALJIC, supra note $67,10.06$.

90. Lewis v. State, 217 Miss. 488, 64 So. 2d 634 (1953). See generally 44 AM. JUR. Rape $\$ 93$ (1942). 
exists that she has consented to sexual relations with all men. And if a woman once submits willingly to a man, the presumption raised by her prior consent means that that man is quite safe in forcing her submission later. The law further insists that if the victim delays in reporting the rape, that delay will be considered a circumstance tending to show she consented to the intercourse. ${ }^{01}$

Because of the fear of false rape complaints, other legal writers have defended corroborative evidence rules, which require some evidence other than the victim's testimony to convict for rape. ${ }^{92}$ A judge, defending the necessity for the New York corroborative evidence rule, which had virtually eliminated conviction for rape, ${ }^{03}$ commented that prosecuting attorneys inust continually guard against charges of rape brought by spurned females seeking revenge or blackmail. ${ }^{04} \mathrm{He}$ categorically stated that "far too many men have been railroaded on sex offense charges." 95 Another writer found that the corroborative evidence rule owes its existence to the "inordinate danger that innocent men will be convicted of rape." ${ }^{\prime}$ He further stated that the word of the complaining witness is "very often false . . . simce stories of rape are frequently lies or fantasies." this conclusion one Michigan case in which the court found a possible motive for a false rape complaint. Only two writers have found no rational basis for inherent suspicion of the victim's testimony. ${ }^{08}$

\section{Sentencing}

The belief that rape is really an uncontrollable urge and that women are basically to blame for rape arises in case law, and it may

91. State v. Risen, 192 Or. 557, 235 P.2d 764 (1951). See generally 44 Ам. JUR. Rape § 103 (1942).

92. See, e.g., 26 GA. CoDe ANN. (Crim. Code) $\$ 26-2001$. Only 7 states presently have corroborative evidence rules. See Note, The Rape Corroboration Requirement: Repeal Not Reform, 81 Yale L.J. 1365, 1367 n.13 (1972).

93. In 1971, Bronx District Attorney Burton Roberts testified before a panel of the New York State Senate to urge that the corroboration requirement (that has since been modified) be repealed. He pointed out that in New York State the "overwhelming majority" of rape cases are dismissed at trial because of the corroboration rule. As it stands now, he said, the law "affords less protection to women and children than it does to personal property." 10 CRIM. L. RPTR. 2120 (1971).

94. Ploscowe, Sex Offenses: The American Legal Context, 25 Law \& Contemp. ProB. 217, 223 (1960). The writer concluded that "no conviction on a sex offense charge should be had where the testimony of the so-called victim is not corroborated by 'other material evidence." "

95. Id.

96. Comment, Corroborating Charges of Rape, 67 CoLUM. L. Rev. 1137 (1967).

97. Id. at 1138.

98. Ludwig, The Case for Repeal of the Sex Corroboration Requirement in New York, 36 BROOKI YN L. Rev. 378, 382 (1970); Note, The Rape Corroboration Requirement: Repeal Not Reform, 81 Yale L. J. 1365, 1378 (1972). 
well be responsible for the imposition of very light sentences by some judges. The disproportionately high percentage of rapists who receive probation ${ }^{99}$ is indicative of peculiar judicial attitudes toward rape. State v. Chaney, ${ }^{100}$ an Alaska supreme court case, exemplifies how these attitudes can affect the sentencing process. The evidence of this case revealed that after the accused and a companion invited the victim into a car, they beat her and raped her four times. The accused forced her to perform fellatio with his companion, took all her money, and threatened her with reprisals if she told the police. The facts apparently were not disputed, and the important question was the severity of the sentence. A military spokesman (the accused was in the Armed Services) told the sentencing court:

An occurrence such as the one concerned here is very common and happens many times each night in Anchorage. Needless to say, Donald Chaney was the unlucky 'G.I.' that picked a young lady who told.101

Despite the undisputed evidence of the brutality of this rape and the unusual severity of the local problem, the trial judge sentenced the accused to two concurrent one-year terms and urged immediate parole.

As the supreme court pointed out in reviewing this sentence, the record was devoid of any trace of remorse by the defendant. The supreme court, feeling that the trial court treated the defendant as though "he was only technically guilty and minimally blameworthy," was sufficiently outraged to order imposition of a stiffer sentence. ${ }^{102}$ Nevertheless, the supreme court stated that the judge properly considered that the victim's voluntary entrance into the defendant's car was a mitigating circumstance, which would properly go to reduce the sentence. ${ }^{103}$

The problem raised by Chaney is not so much the light sentence imposed by the trial judge, but the judge's attitude that rape is not really a crime deserving punishnient. Where attitudes about rape, based on misconceptions, lead judges to believe that the victims are always to blame, the sentencing of defendants is apt to be arbitrarily light. Although light sentences may be generally sufficient in terms of deterrence and rehabilitation, each case should be decided on its facts and not under the prejudice that rape is acceptable behavior.

\section{Summary}

The fear of the inaniac and the genuine desire to protect chaste,

99. See notes 43,44 , and 72 , supra.

100. 477 P.2d 441 (Alaska 1970).

101. Id. at 446, n.24.

102. Id. at 447.

103. Id. at 446-7. 
totally innocent women from sexual assault clash mightily with the fear of convicting innocent men. As a result, we have on one hand harsh penalties for rape; on the other, however, we have few convictions and a myriad of laws and attitudes that tend to protect men from conviction except when the complainant is a chaste, mentally healthy woman who reports the attack promptly, and who is willing and able to undergo the horrors of a rape trial.

Furthermore, rape laws regard the nonmarital sexual activity of men as irrelevant to the rapist's veracity, yet the non-marital sexual activity of the woman condemns her. The sexually active woman is not only regarded as a liar, she is considered fair game. Such a double standard, which considers male sexuality normal and female sexuality abnormal, serves to enhance the dichotomy between the "good" woman, who is the sole sexual possession of one male, and the "bad" woman who, lacking status as a sole possession, functions as the outlet for "normal" male promiscuity and therefore cannot be raped.

\section{IV}

\section{SUGGESTIONS FOR REFORM}

Rape laws are structured so as to frighten would-be rapists by potentially heavy sentences and at the same time to prevent the conviction of rapists except in rare instances where the offense is so outrageous that sentiment of the police, prosecutors, judge, and jury, overpowers the mechanisms that mpede conviction. Jury antagonism to rape victims ("she was asking for it;" "she could have resisted") is blamed by prosecutors for the low conviction rate, but the cumulative effect of the cautionary instructions probably gives the jury little choice but to acquit in a great many cases. The jury is told that a charge of rape is easily made and difficult to defend against and that the victim's testimony must be examined with caution. Even if the jury is told that corroborative evidence is not necessary, they are generally bombarded with evidence of the "unchastity" of the victim, which, they are told, discredits her testimony. If she has delayed reporting the rape or if she has refused to subnnit to a medical examination, her testimony is partially discredited. If she refuses to submit to a court-ordered psychiatric examination or if she is found to be mentally unbalanced, her testimony is further discredited. If evidence is presented that she previously consented to intercourse with the accused, her testimony is almost entirely discredited.

Nothing comparable to these restrictions exists elsewhere in crimmal law. If, for example, a woman brings a charge of kidnapping, and the question of her consent to be moved depends upon whether 
the testimony of the accused or the victim is more credible, no set of laws comparable to rape laws comes into play to protect the accused. As far as the jury's ability to resolve the issues is concerned however, there seems to be no substantial difference between an uncorroborated charge of kidnapping and an uncorroborated charge of rape. Juries exist, after all, to decide whose testimony is most credible, and they are instructed to convict only if satisfied of the accused's guilt. There should be no special rules for rape.

The most unrealistic aspect of rape law is the treatment of the victim's "chastity" in court. The concept of "chastity" is apparently based upon the nineteenth century view that there are two kinds of women: "good" and "bad." Those who are either faithful wives or virgins deserve the law's protection; women outside these groups are deemed unworthy of protection. The sharp differentiation between the faithful wife or virgin on one hand and the "loose" woman on the other has long simce disappeared, and its central role in rape law is, at best, anachronistic. The courts should take judicial notice of the fact that a great many women in our society have sexual relations outside the marriage relationship. ${ }^{104}$ The chastity requirement today places significant numbers of women, rather than a few outcasts, beyond the protection of the law. Atteinpts to introduce evidence of unchastity into rape trials should be rejected altogether. The relationship between a wornan's chastity and whether or not she has been raped is simply too attenuated to warrant consideration as relevant evidence.

The reluctance of police and prosecutors to proceed with complaints involving an accused previously known to the victim suggests the difficulty in securing convictions in such cases. In view of the large number of rapes committed by men known to their victims, however, it is essential that juries not be permitted to assume that such previous acquaintance undercuts the victim's credibility. Evidence concerning the prior relationship of victim and accused should be admissible only for the purpose of showing a bad faith motive by the complainant in making the charge or in verifying the identification of the accused. Instructions should carefully caution the jury against assum-

104. Although little study of extramarital sexual behavior has taken place recently, a 1970 study of 4,220 high school students in three midwestern communities revealed that 26 percent of the 17 year old women had engaged in premarital coitus. Vener and Stewart, The Sexual Behavior of Adolescents in Middle America: Generational and American-British Comparisons, 34 J. OF MARRIAGe and the Family 696, 699 (Nov. 1972). Furthermore, a study of 688 college women from 21 American colleges showed that 43.2 percent reported they had had premarital intercourse. Luckey and Nass, $A$ Comparison of Sexual Attitudes and Behavior in an International Sample, 31 J. OF MARRIAGE AND THE FAMILY 364, 375 (May 1969). 
ing that the bare existence of a.prior relationship is otherwise relevant to the victim's credibility.

Much of the fear of convicting innocent men could be overcome if scientific techniques for reconstructing the sexual acts charged were fully exploited. Prosecutorial discretion is minimally regulated, but it would not be unreasonable for the law to require that this discretion be based upon an examination of all facts potentially available to the prosecutor-including such scientific data.

Punishment of the rapist also should be reevaluated. California procedures for mentally-disordered sex offenders ${ }^{105}$ may help control the psychopathic rapist, but little has been done to discourage the more frequently encountered "normal" rapist. Potentially high sentences probably serve more to deter victims from, complaining and juries from convicting than they serve to deter rapists from raping. ${ }^{100}$ Lower maximum sentences, along with inandatory psychiatric evaluation, would probably be more effective in securing convictions. Serious consideration might be given to castration ${ }^{107}$ as a rehabilitative technique as used in European countries where it is generally performed with the rapist's consent and is accompanied by intensive psychotherapy. ${ }^{108}$ Castration instead of prison may well be a choice that the convicted rapist should be permitted to make. A major defect in this proposal, however, is that castration of rapists would tend to reinforce the myth that rapists are abnormal men seizedl by uncontrollable urges and that the problem is physical and psychological rather than societal.

105. CAX. WELF. \& INST'NS CODE $\$ 6300$ et seq. (West 1972).

106. Although the effect that decreased penalties would have on rape is unknown, one study has been conducted to determine the effect of increased penalties on rape. Schwartz, The Effect in Philadelphia of Pennsylvania's Increased Penalties for Rape and Attempted Rape, 59 J. CRIM. L. \& C.S. 509 (1968). After a particularly brutal rape in 1966, an end was put to all continuances on trials for those accused of crimes leading to bodily injury in Philadelphia. The state shortly thereafter passed a law providing for sentences up to life imprisonment and fines up to $\$ 10,000$ for those convicted of rape involving serious bodily injury. The following year the number of reported and atteinpted rapes in Philadelphia was the same as it had been before the new laws [id. at 511]; the proportion of rapes to attempted rapes had increased slightly [id. at 512]; and the injury to the victions remained the same [id. at 514]. It thus seems clear that increased penalties for rape do not give increased protection to woinen.

107. Castration is defined as removal of the testes in the male and the ovaries in the fernale.

108. There is precedent for the castration of criminals in this country. In the past, California provided for the compulsory asexualization (castration) of the recidivist in state prison who had given evidence while in prison that he was a "moral or sexual degenerate or pervert." Those serving life sentences could be castrated even if they were not recidivists. CAx. PENAX CODE $\$ 2670$, enacted in 1941 and repealed in 1971. The statute was never tested in the courts. For an examination of the use of 
Consideration should also be given to whether it makes sense to limit rape to cases of penetration of the vagina by a penis. Since the offense actually consists of a sexual outrage to the person, that outrage should probably include a broader range of sexual contact. ${ }^{109}$ In any case, there is no sound reason for restricting rape to male offenders and female victims. Men who are sexually assaulted should have the same protection as female victims, and women who sexually, assault men or other woinen should be as hable for conviction as conventional rapists. Considering rape as a sexual assault rather than as a special crime against women might do much to place rape law in a healthier perspective and to reduce the mythical elements that have tended to make rape laws a means of reinforcing the status of women as sexual possessions.

\section{CONCLUSION}

Available statistics indicate that rapes not only are theavily under-reported, but are also increasing very rapidly. Contrary to popular belief, rapes are generally planned, imvolve physical force, and are committed by normal young men who are often acquaimted with their victims. There are few false rape complaints, and these are easily disposed of by the police. Apprehended rapists are rarely convicted of rape. Scientific imvestigation, although of great value, is seldom conducted or, if conducted, is seldom used by the police.

On the other hand, there exists a great network of laws and attitudes based on the assumptions that false rape complaints are plentiful and that innocent men can easily be convicted of rape. As the facts show, both these assumptions are generally unfounded. An entire legal franework of myths and stereotyped preconceptions unrelated to reality has been constructed. This gulf between myth and reality necessitates reevaluation of rape laws. A reconstruction of these laws with careful attention to the reality of rape could not only make the disposition of rape charges and convictions more efficient and more fair, but it could also serve to promote a much needed change in society's attitude toward rape.

Camille E. LeGrand

castration in Scandinavian countries, see Stürup, Sex Offenses: The Scandinavian Experience, 25 LAW \& CONTEMP. PROB. 361 (1960).

109. Sexual intercourse might be defined as contact between "the mouth and the anus, the mouth and the penis, the mouth and the vulva, or between the peris and the vulva, or the penis and the anus, or between the anus or the vulva and any artificial substitute," as suggested to the New York legislature by the Women's Rape Council. If the chance of pregnancy is serious enough to warrant a heavier penalty for contact between penis and vulva, then this could be accomplished by setting up degrees of rape. 